\title{
塩粉末を用いたスパークイオン源質量分析法による 鉄鋼中の不純物の定量
}

\author{
斉藤 守正，須藤 恵美子*
}

$(1975$ 年 3 月 12 日受理 $)$

\begin{abstract}
スパークイオン源質量分析法による鉄鋼中の不純物の定量を，試料を内標準のイットリウムとともに 酸に溶解・乾固した塩粉末を用いる方法（ここでは塩粉末法と呼ぶ）によって検討した。NBS の低合 金銅の標準試料を用いて各元素の相対感度係数を求めた結果，スズ，モリブデン，銅，ニッケル，コバ ルト，クロム，バナジゥム，リン，ホウ素などの元素に対しては，本法は從来の固体法とよい一致を示 し,しかも精度が約 $10 \%$ 向上した. しかし, ニオブ，タンタル，硫黄などの元素に対しては精度が悪 く，これらの金属の定量には問題を残した，本法によって NBS のステンレス鋼，日本鉄鋼（JSS）の 標準試料普通鋼，工具銅に応用し，正確さ，精度とも良好な結果が得られた。又，本法がマトリックス 効果を小さくすること，均一な試料が得られやすいことなどが分かった。
\end{abstract}

\section{1 緒 言}

スパークイオン源斦量分析法は, 高感度であるので極 微量元素の定量が可能で, しかも少量の試料で多元素を もれなく検出できる利点があるが，試料の均一性，マト リックスの影響, 更にはスパークギャップなどスパーク の安定性, 乾板検出法を用いた場合には乾板の均一性, モニター電荷計の精度など装置上の問題があって精度が 悪いのが現状である.

スパーク放電電極用として用いられている試料形態に より固体法, 溶液法, 粉末法1) 3)などがある. 鉄鋼試料 では通常は固体試料をとのまま電極として分析を行う方 法が多く用いられているが，この方法では試料の均一 性, 化合物形態などによる影響, いわゆるマトリックス 効果が無視できず分析精度は（10３0）\%ぐらいばらつ く4). 溶液法には, 高純度黑鉛など導電性物質に吸着乾

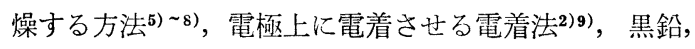
金などの粉末と混合吸収させる方法 ${ }^{8)}$ 15)，試料溶液を 凍結させる凍結法などの方法がある. 溶液法は操作が煩 雑で実用上問題があるが，内標準法が適用できること， マトリックスの影響を小さくすることができることなど の利点があり，最近は二，三の金属塭化合物をドープレ て金粉末と混合して電極に成形した分析試料を用いて精

* 金属材料技術研究所 : 東京都目黑区中目黑 2-3-12
度が向上したという報告がある10111，そこで著者らは， 溶液法の利点をいかし，更に実用性も考慮して試料を酸 に溶解・乾固し，その乾固物と黒鉛粉末とを混合，電極 に成形し，分析試料とする塩粉末法による新しい方法を 考えた，通常鉄鋼中には存在せず，質量数 89 で他の元 素への影響が小さく，しかも乾板のほぼ中央にスペクト ル線が位置するイットリウムを内標準に使用して, 固体 法より精度が向上することを確かめた．これらの点につ いて報告する。

\section{2 実験}

\section{1 装 是}

使用した装置は AE1 MS7 二重収束質量分析器で, 検 出には Ilford $\theta 2$ 乾板 $\left(2^{\prime \prime} \times 10^{\prime \prime}\right)$ を用いた。モニター 電荷計は国際電気(株)製ソリッドステート型のものを使 用した．塩粉末試料と黑鉛粉末との混合にはスペックス 製の混合機 (No. 8000), 容器, ボールなどはプラスチ ック製のものを用いた。加圧成形は小西らの報告にあ る1) 角型のモールドを改良したものを使用した。ミミクロ ホトメータは理学電気(株)製 CM-1A 型（観測スリッ 卜幅 $50 \mu$ ，測定主スリット幅 $5 \mu$ ，スリット高さ 0.5 $\mathrm{mm}$ ) である. 試料の乾燥には Heidon-VAA 型の微量 真空乾燥器を用いた.

\section{2 供試料及び試薬}

供試料は NBS ステンレス鋼（442），日本鉄鋼標準試 
料普通鋼（JSS 461-2), 工具鋼（JSS 602-2）で，相対 感度係数を求めるのに使用した標準試料は NBS 462, 464，466，467 の 4 種である. NBS の 460 シリーズの 標準試料は棒状であるので旋盤で直径 $(2 \sim 3) \mathrm{mm}$ ，長さ (15〜20) $\mathrm{mm}$ の大きさの電極を 2 本作成し固体法の試料 に供し，六のときできた切りくずを塩粉末法の試料に 使用した。内標準に使用したイットリウムは Johnson Matthey 製の酸化イットリウム $\left(\mathrm{Y}_{2} \mathrm{O}_{3}\right)$ である. 黑鉛 粉末はリングドリフ製高純度ブリケット用を用いた。試 料溶解に使用した塩酸, 硝酸などはすべて特級試薬であ る.

\section{$2 \cdot 3$ 実験方法}

試料約 $(0.5 \sim 1) \mathrm{g}$ を内標準用の酸化イットリウム（試 料との重量比で約 1\%) とともに $50 \mathrm{ml}$ ビーカ一中で 塩酸 $(1: 1)$, 硝酸 $(1: 1)$, 又は塩酸と硝酸の混酸で加 熱溶解する. 加熱時は時計ざらなどでふたをする．使用 する酸はできるだけ少量で加熱溶解し，乾固するまで加 熱する. 乾固直前に， $(60 \sim 70)^{\circ} \mathrm{C}$ の温度に保った真空 乾燥器に移し, 真空にして約 1 時間乾燥する. 冷却後, 試料を乾燥器から取り出し，めのう乳ばちに移す. スパ チュラなどでできるだけ完全にめのう乳ばちに移し，均 一に粉砕する. 粉砕後直ちに等量（重量比）の高純度黒 鉛粉末を入れ混合機で 2 分間混合し, 試料作成用モール ドで長さ $20 \mathrm{~mm}, 2.5 \mathrm{~mm}$ 角の電極を 2 本作成し分析 試料とする. 分析試料は潮解性が大きいので保存には真 空中あるいはアルゴンガスで置換した容器中で保存す る.

装置の測定条件は主スリット $120 \mu$, スパーク電圧 40 $\mathrm{kV}$ ，パルス繰り返し数 $(10 \sim 300) \mathrm{Hz}$ ，パルス幅 $25 \mu \mathrm{s}$, イオン加速電压 $20 \mathrm{kV}$ である. 露出量は $\left(1 \times 10^{-12}\right.$ ～ $\left.3 \times 10^{-9}\right)$ クーロンで 1 枚の乾板に 2 回測定した。乾板 の現像は ID- $19,20^{\circ} \mathrm{C}$ で 4 分間行い, 定着はフジフィ ックスを使用して 3 分間行い，水洗を（20３0）分開行 った後, 自然乾燥した.

スペクトル線はミクロホトメーターで透過率を測定し た・検量線は通常用いられるスペクトル線の透過率をザ ィデル (Seidel) 関数 $\Delta(\log 1 / T-1)$ に変換した值を モニタ一電荷計で得られる露出量に対してプロットして 求めた。

不純物元素の定量は Waldron の式に乳剂感度に対す る補正係数 $\sqrt{M}$ を入れた式（1）によって計算した。

$$
\begin{aligned}
& C_{\mathrm{imp}}(\%)=\left(E_{\mathrm{st}} \cdot I_{\mathrm{st}} \cdot \sqrt{M_{\mathrm{imp}}} \cdot N_{\mathrm{imp}} \cdot S_{\mathrm{st}}\right) / \\
& \quad\left(E_{\mathrm{imp}} \cdot I_{\mathrm{imp}} \cdot \sqrt{M_{\mathrm{st}}} \cdot N_{\mathrm{st}} \cdot S_{\mathrm{imp}}\right) \times C_{\mathrm{st}} \cdots(1)
\end{aligned}
$$

ここで $C_{\mathrm{imp}}, C_{\mathrm{st}}$ は各元素の不純物あるいは内標準 に用いたイットリウム，鉄の重量パーセントをそれぞれ
示している．Eは各元素のザイデル関数 $\Delta$ が零になる モニタ一電荷計で測定される露出量, $I$ は同位体存在率 $(\%), \sqrt{M}$ はイオン質量による乳剂感度に対する 補正 係数, $N$ は原子量, $S$ は相刘感度係数を示す.

\section{3 結果及び考察}

\section{1 相対感度係数}

式（1）における相対感度係数 $S$ は，標準試料などを 用いて主元素，あるいは内標準元素に対してあらかじめ 求めておく必要があるが，本研究では NBS 462，464, 466，467の低合金鋼の 標準試料を用いて 相刘感度係数 を求めた。試料溶解にはすべて塩酸を用いた塩粉末法で は各試料とも 6 回独立に測定して得られた檤の平均した 值を Table 1 に示す.

Table 1 には，塩粉末法で用いた同じロットの試料を 用い，塩粉末法と同様な条件で各試料とも 6 回測定した ときの固体法の相対感度係数の值も示したが, 塩粉末法 上固体法とを比較してみると，二オブ，タングステン， ヒ素, チタンを除いて, スズ, モりブテン, 銅, ニッケ ル, コバルト, マンガン, クロム, バナジウム, 硫黄, リン, ケイ素, ホウ素の各元素は両者ともよく一致して いる.このことは, 固体試料, 粉末試料ともスパーク時 のイオン化効率は注とえど変わらないことを示している と考えられる.

塩粉末法においてイットリウムを内標準として求めた 相対感度係数は鉄を内標準として求めた值よりわずかに 高い值を示した. 又，イットリウムを内標準にして求め たほうが鉄を内標準にして求めた場合より精度が良い值 が得られた. 鉄のほうがイットリウムより精度が悪くた った原因は，イットリウムの場合は他の不純物元素とほ 汸同じ含有量に調製することができスペクトル線の測定 を容易にするが，鉄のスペクトルは低い露出量で検出さ れるのでモニター電荷計の精度が悪い露出量の所で検量 線を描くためと考兄られる.

イットリウムを内標準に使用した場合の塩粉末法の精 度は, 固体法に比べてスズ，モリブテン，七素，銅，二 ッケル，コバルト，クロム，バナジウム，千タン，リン， ホウ素などでは平均して $10 \%$ ぐらい良くなった。しか しニオブ，硫黄は精度が非常に悪い. 塩粉末法で二オ ブ, タングステン，チタン，七素の各元素が固体法と比 ベ相対感度係数が異なった値が得られたり，ニオブ，硫 黄が精度の非常に悪い值が得られたのは, 試料を塩酸で 加熱溶解するのに問题があったためと思われる.しかし 試料作成時の污染，あるいはこれらの金属が黒鉛と均一 に混合されないためとも考えられ，これらの点に関して 
Table 1 Relative sensitivity coefficient (R. S. F.) in iron matrix

\begin{tabular}{|c|c|c|c|c|c|c|c|c|}
\hline \multirow{3}{*}{ Element } & \multirow{3}{*}{\multicolumn{2}{|c|}{ Contents (\%) }} & \multirow{2}{*}{\multicolumn{2}{|c|}{$\begin{array}{l}\text { Solid } \\
\mathrm{Fe}=1\end{array}$}} & \multicolumn{4}{|c|}{ Powder } \\
\hline & & & & & \multicolumn{2}{|c|}{$\mathrm{Fe}=1$} & \multicolumn{2}{|c|}{$\mathrm{Y}=1$} \\
\hline & & & R. S. F. & C. V. $(\%)$ & R.S.F. & C. V. $(\%)$ & R.S.F. & C. V. $(\%)$ \\
\hline W & $(0.0011)$ & $\sim 0.20$ & 0.23 & 26.3 & 2.4 & 19.0 & 2.7 & 18.1 \\
\hline Sn & 0.005 & $\sim 0.16$ & 1.8 & 30.0 & 1.0 & 27.1 & 1.2 & 20.2 \\
\hline Mo & 0.01 & $\sim 0.08$ & 0.43 & 19.7 & 0.48 & 17.3 & 0.48 & 14.2 \\
\hline $\mathrm{Nb}$ & 0.005 & $\sim 0.29$ & 0.66 & 28.1 & 5.8 & 44.6 & 6.8 & 49.1 \\
\hline As & 0.046 & $\sim 0.14$ & 0.65 & 32.1 & 0.30 & 27.0 & 0.30 & 19.7 \\
\hline $\mathrm{Cu}$ & 0.030 & $\sim 0.20$ & 1.8 & 25.2 & 1.5 & 12.8 & 1.8 & 10.3 \\
\hline $\mathrm{Ni}$ & 0.05 & $\sim 0.70$ & 1.1 & 22.9 & 1.2 & 18.5 & 1.3 & 13.3 \\
\hline Co & 0.046 & $\sim 0.11$ & 0.76 & 23.2 & 1.2 & 12.6 & 1.3 & 12.2 \\
\hline $\mathrm{Mn}$ & 0.11 & $\sim 0.94$ & 3.0 & 16.8 & 1.5 & 13.5 & 2.0 & 10.1 \\
\hline $\mathrm{Cr}$ & 0.01 & $\sim 0.74$ & 1.8 & 30.0 & 1.6 & 17.9 & 1.7 & 13.6 \\
\hline $\mathrm{V}$ & 0.007 & $\sim 0.06$ & 1.4 & 20.1 & 1.1 & 18.0 & 1.4 & 14.9 \\
\hline $\mathrm{Ti}$ & 0.04 & $\sim 026$ & 2.0 & 25.0 & 1.0 & 20.0 & 1.0 & 16.7 \\
\hline $\mathrm{S}$ & $(0.01)$ & $\sim(0.02)$ & 1.0 & 25.6 & 0.91 & 35.8 & 1.0 & 31.8 \\
\hline $\mathrm{P}$ & 0.01 & $\sim 0.05$ & 0.40 & 23.1 & 0.41 & 18.6 & 0.50 & 15.0 \\
\hline $\mathrm{Si}$ & 0.025 & $\sim 0.28$ & 0.97 & 22.5 & 1.2 & 20.8 & 1.3 & 17.4 \\
\hline \multirow[t]{2}{*}{ B } & $(0.000$ & 1) $\sim 0.005$ & 1.2 & 20.6 & 1.1 & 14.5 & 1.2 & 12.3 \\
\hline & & & \multicolumn{2}{|r|}{$\overline{\bar{x}}=24.5$} & \multicolumn{2}{|r|}{$\overline{\bar{x}}=21.1$} & \multicolumn{2}{|r|}{$\overline{\bar{x}}=18.1$} \\
\hline
\end{tabular}

は明らかでなく，現在詳しいことを検討中である。良い て現在のとこう塩粉末法では，ニオブ，硫黄，チタン炎 どの元素は定量が困難であることが分かった.

酸で試料を溶解する場合，低合金鋼の試料では塩酸で ほぼ完全に溶解するが，合金鋼の中には硝酸，過塩素酸 などの酸化性の強い酸を使朋する必要があるものもあ り，このような酸化性の強い酸を使用した場合は試料溶 解・乾固, 粉末にしたとき潮解性が強く, 試料の取り扱 いが困難になる傾向があった。文，酸化性の強い酸を使 用した場合の結果は，低合金鋼の場合は塩酸を使用した 場合の結果と同じであった.

\section{2 定量結果}

以上求めた相対感度係数を用いて, 実際試料に応用し てみた. 用いた試料は NBS 442 ステンレス鋼, JSS 461 -2 普通鋼, JSS 602-2 工具鋼の各標準試料である.
テンレス鋼，普通鋼，工具鋼のそれぞれの試料について 6 回独立に測定した定量結杳をTable 2，3，4 にそれぞ れ示す.ステンレス鋼では試料溶解には塩酸を使用した が，二オブ，チタンは正確さ，精度とも悪かったが，モ リブデン，スズ，銅，ニッケル，コバルト，マンガン， クロム, バナジウムの各元素は精度, 正確さとも良好な 結森が得られた。しふし，普通鋼の場合も試料溶解には 塩酸を用いたが，モリブデン，七素，硫黄，ケイ素の精 度は低い值を示した. 工具鋼の試料では試料溶解には塩 酸, 硝酸の混酸を用いたが, タングステン, 硫黄の精度 が非常に悪い值を示し, 外の元素は精度, 正確さともに 良好であった。これらの結果より，ニオブ，チタン，硫 黄, ヒ素, タングステンなどの金属の定量は精度が悪く, 定量には問題があることが分かった. 又，モリブデンは 試料によって精度が悪くなることがあったが，この原因 については明らかでない.

Table 2 Determination of elements in stainless steel (NBS 442)

\begin{tabular}{|c|c|c|c|c|c|c|c|c|c|c|}
\hline Elements & $\begin{array}{c}\text { Certified } \\
\text { values }(\%)\end{array}$ & & & Foun & $(\%)$ & & & $\bar{x}(\%)$ & $\sigma$ & C. V. $(\%)$ \\
\hline $\mathrm{S}_{\mathrm{n}}$ & 0.0035 & 0.0033 & 0.0034 & 0.0043 & 0.0033 & 0.0053 & 0.0050 & 0.0041 & 0.0008 & 19.5 \\
\hline Mo & 0.12 & 0.20 & 0.12 & 0.17 & 0.20 & 0.11 & 0.12 & 0.15 & 0.031 & 21.0 \\
\hline $\mathrm{Nb}$ & 0.0 .5 & 0.075 & 0.025 & 0.060 & 0.16 & 0.093 & 0.015 & 0.072 & 0.053 & 74.1 \\
\hline $\mathrm{Cu}$ & 0.11 & 0.089 & 0.094 & 0.12 & 0.11 & 0.10 & 0.094 & 0.10 & 0.012 & 12.0 \\
\hline $\mathrm{Ni}$ & 9.9 & 6.5 & 11.5 & 14.0 & 11.0 & 8.2 & 7.1 & 9.7 & 2.65 & 27.0 \\
\hline Cos & 0.13 & 0.17 & 0.12 & 0.07 & 0.14 & 0.12 & 0.12 & 0.12 & 0.020 & 16.5 \\
\hline $\mathrm{Mn}$ & 2.88 & 3.3 & 2.8 & 4.2 & 4.5 & 4.2 & 3.2 & 3.7 & 0.48 & 12.9 \\
\hline $\mathrm{Cr}$ & 19 & 14.0 & 14.1 & 11.5 & 7.9 & 19.0 & 16.0 & 13.7 & 2.5 & 11.8 \\
\hline$V$ & 0.032 & 0.029 & 0.026 & 0.039 & 0.024 & 0.040 & 0.021 & 0.030 & $0.007_{2}$ & 24.0 \\
\hline $\mathrm{Ti}$ & 0.0020 & 0.0015 & 0.0026 & 0.014 & 0.0019 & 0.0038 & 0.018 & 0.0070 & 0.0065 & 93.3 \\
\hline B & 0.0005 & 0.00038 & 0.00038 & 0.00074 & 0.00055 & 0.00041 & 0.00041 & 0.00047 & 0.00009 & 19.0 \\
\hline
\end{tabular}


Table 3 Determination of elements in plain carbon steel (JSS 461-2)

\begin{tabular}{|c|c|c|c|c|c|c|c|c|c|c|}
\hline \multirow{2}{*}{$\frac{\text { Elements }}{\mathrm{Sn}}$} & \multirow{2}{*}{$\begin{array}{c}\text { Certified } \\
\text { values (\%) }\end{array}$} & \multicolumn{6}{|c|}{ Found $(\%)$} & \multirow{2}{*}{$\frac{\bar{x}(\%)}{0.0055}$} & \multirow{2}{*}{$\frac{\sigma}{0.0008}$} & \multirow{2}{*}{$\frac{\text { C. V. }(\%)}{16.4}$} \\
\hline & & 0.0063 & 0.0062 & 0.0057 & 0.0054 & 0.0038 & & & & \\
\hline Mo & 0.008 & 0.012 & & 0.015 & 0.0067 & 0.0088 & 0.0052 & 0.0095 & 0.0036 & 37.9 \\
\hline As & 0.018 & 0.0097 & 0.018 & 0.013 & 0.0067 & 0.012 & 0.0037 & 0.011 & 0.0046 & 41.8 \\
\hline $\mathrm{Cu}$ & 0.060 & 0.049 & 0.067 & 0.057 & 0.056 & 0.037 & 0.067 & 0.055 & 0.010 & 18.2 \\
\hline $\mathrm{Ni}$ & 0.028 & 0.041 & 0.046 & 0.025 & 0.030 & 0.025 & 0.021 & 0.031 & 0.0091 & 29.4 \\
\hline $\mathrm{Mn}$ & 0.79 & 0.90 & 1.1 & 0.75 & 0.85 & 0.75 & 0.90 & 0.88 & 0.12 & 13.6 \\
\hline $\mathrm{Cr}$ & 0.043 & 0.038 & 0.035 & 0.034 & 0.039 & 0.031 & 0.029 & 0.034 & 0.0036 & 10.6 \\
\hline $\mathrm{S}$ & 0.014 & 0.0090 & 0012 & 0.014 & 0.029 & 0.0022 & 0.0092 & 0.013 & 0.0082 & 63.1 \\
\hline $\mathrm{P}$ & 0.026 & 0.012 & 0.016 & 0.022 & 0.024 & 0.020 & 0.015 & 0.018 & 0.0042 & 23.3 \\
\hline $\mathrm{Si}$ & 0.19 & 0.21 & 0.15 & 0.11 & 0.12 & 0.075 & 0.054 & 0.12 & 0.051 & 42.5 \\
\hline
\end{tabular}

Table 4 Determination of elements in tool steel (JSS 602-2)

\begin{tabular}{|c|c|c|c|c|c|c|c|c|c|c|}
\hline \multirow{2}{*}{$\frac{\text { Elements }}{\mathrm{W}}$} & \multirow{2}{*}{$\frac{\begin{array}{c}\text { Certified } \\
\text { values }(\%)\end{array}}{3.29}$} & \multicolumn{6}{|c|}{ Found $(\%)$} & \multirow{2}{*}{$\frac{\bar{x}(\%)}{5.2}$} & \multirow{2}{*}{$\frac{\sigma}{1.4}$} & \multirow{2}{*}{$\frac{\text { C. V. }(\%)}{27.3}$} \\
\hline & & 3.1 & 5.0 & 6.1 & 7.4 & 4.5 & 4.9 & & & \\
\hline Mo & 0.082 & 0.060 & 0.080 & 0.068 & 0.088 & 0.10 & 0.074 & 0.078 & 0.014 & 17.9 \\
\hline $\mathrm{Cu}$ & 0.020 & 0.016 & 0.022 & 0.017 & 0.017 & 0.020 & 0.023 & 0.019 & 0.0029 & 15.4 \\
\hline $\mathrm{Ni}$ & 0.015 & 0.021 & 0.015 & 0.016 & 0.020 & 0.013 & 0.014 & 0.017 & 0.0024 & 14.5 \\
\hline $\mathrm{Mn}$ & 0.33 & 0.31 & 0.37 & 0.39 & 0.32 & 0.26 & 0.37 & 0.34 & 0.039 & 11.5 \\
\hline $\mathrm{Cr}$ & 0.44 & 0.39 & 0.39 & 0.54 & 0.37 & 0.39 & 0.34 & 0.40 & 0.064 & 15.8 \\
\hline $\mathrm{V}$ & 0.20 & 0.16 & 0.14 & 0.20 & 0.14 & 0.15 & 0.15 & 0.16 & 0.023 & 14.6 \\
\hline $\mathrm{S}$ & 0.017 & 0.0090 & 0.018 & 0.017 & 0.0067 & 0.017 & 0.031 & 0.016 & 0.0077 & 48.1 \\
\hline $\mathbf{P}$ & 0.013 & 0.016 & 0.015 & 0.020 & 0.014 & 0.019 & 0.016 & 0.017 & 0.0027 & 16.2 \\
\hline $\mathrm{Si}$ & 0.27 & 0.40 & 0.45 & 0.38 & 0.27 & 0.22 & 0.39 & 0.39 & 0.088 & 22.9 \\
\hline
\end{tabular}

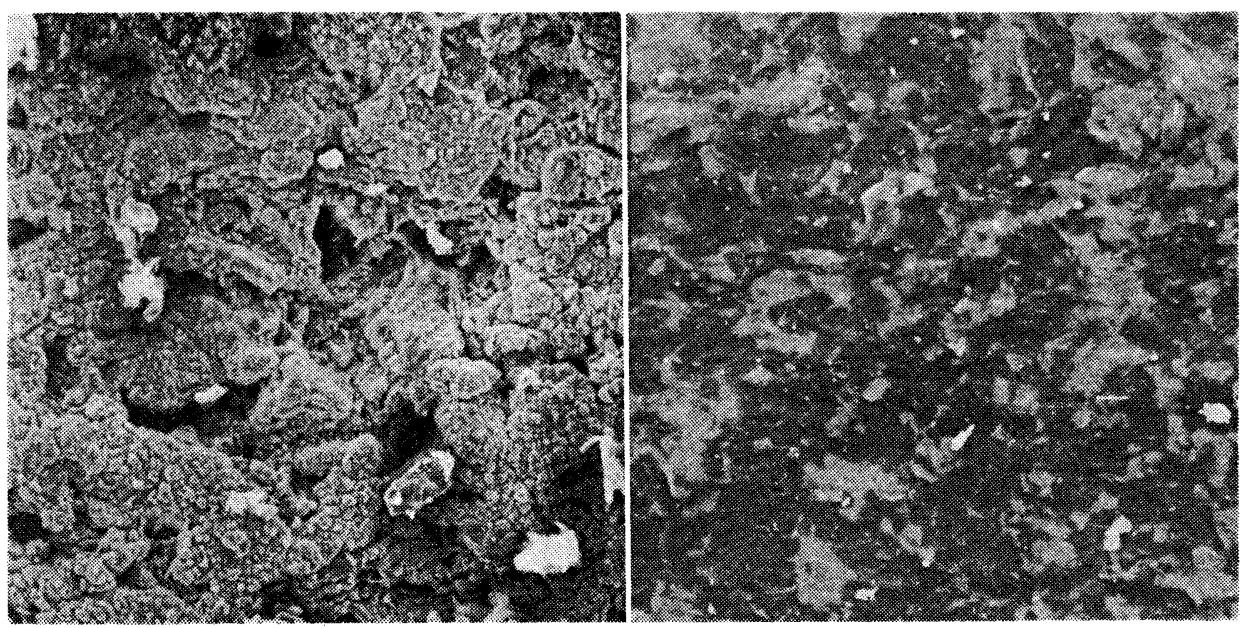

Photo. 1 Scanning electron microfractographs of samples of powdered salts $(\times 300 \times 3 / 5)$ (a) Sample (NBS 467) of powdered salts (50 wt\%); (b) Sample (NBS 467) of powdered salts after spark

\section{3 試料の均一性}

固体試料を用いる場合, 試料の偏析が大きいと定量值 に大きく影響を与元，又試料の化合物形態，履歴などに よるマトリックスの影響も無視できないといわれてい る. 粉末試料を用いる方法は, 絶䋑物でも容易に使用で き，内標準法が利用でき，標準用試料の合成が容易であ るなどの利点がある、一般に不純物が少ないことから高
純度黒鉛粉末が金属などとの混合によく用いられるが， 金属は黒鉛に比べて比重が大きく，これらを均一に混合 するには多くの労力を必要とする難点がある.

塩酸で試料を溶解して得られた塩粉末はほとんどの金 属が塩化物になっており, これらの塩化物の多くは比重 2 3 の範囲にあるので, 黒鉛粉末との均一混合に有利 であると思われる. Photo. 1 には塩粉末法の試料電極 
の表面観察を走查型電子顕微鏡で調ベた結果の 1 例を示 してあるが，塩化物と黒鉛粉末とが均一に混合している ことが分かる．このことより，塩粉末はスパークイオン 源質量分析用の試料として優れていることが明らかにな った．黑鉛粉末の代わりに金，銀粉末を使用できるが， これらの金属は一般に不純物の多いものが多く, 不純物 の少ないのが入手できず良好な結果は得られなかった。 これらの金属の高純度の粉末があれば更に利用範囲が広 がるものと思われる. 以上のことより本法はマトリック スの影響を小さくしているばかりでなく, 均一な試料が 得やすいため定量精度が向上したと思われる. 又, 本実 験は乾板検出法で行ったが，電気検出法で行えば更に精 度が向上するものと期待される.

$$
4 \text { 結 } \overline{\overline{\bar{n}}}
$$

スパークイオン源質量分析法により鉄鋼中の不純物の 定量について試料を酸で溶解・乾固し，乾固物と黑鉛と を混合，加压成型した分析試料を用い，イットリウムを 内標準に用いる方法について検討し，スズ，モリブデ ン, 銅, コバルト, クロム, リン，ホウ素，マンガンな どの金属が精度よく定量できることを確かめた．又，本 法と固体法とによる相対感度係数を比較した結果，両者 は比較的よい一致を示した，従って，本法によりマトリ ックスの影響が小さくなり，均一な試料が得られること が分かった、しかしチタン，ニオブ，硫黄，七素などの 元素は，正確さ及び精度が覀く，これらの金属の定量に は問題が残されている.

\section{(1973 年 11 月, 日本分析化学 $)$ 会第 22 年会に拈いて発表}

\section{交献}

1) F. Konishi : Mass Spectroscopy (Japan), 16, 251 (1968).

2) G. H. Morrison, J. R. Roth : "Trace Analysis by Mass Spectrometry", Edited by A. J. Ahearn, p. 297 (1972), (Academic Press).

3) R. L. Beveridge : Appl. Spectrosc., 27, 271 (1973).

4)山口直治 :「固体質量分析法の鉄鋼業への応用」シ ンポジウム論交集, p. 1 (1974), (日本鉄鋼協会).

5) A. J. Ahearn : J. Appl. Phys., 32, 1197 (1961).

6) V. M. Gladskoi, G. A. Nanova, T. A. Kazuolav, Kuz'min : Z. Anal. Khim., 26, 1087 (1971).

7) 須藤恵美子, 高橋 務：日本分析化学会第 19 年 会講演要旨集, p. 238 (1970).

8) T. A. Carter, A. E. Cameron, J. A. Dean : Anal. Lett., 4, 337 (1971).

9) J. Kai, M. Watanabe : Mass Spectroscopy (Japan), 16, 241 (1968).

10) R. J. Guidoboni, C. A. Evans : Anal. Chem., 44, 2027 (1972).
11) A. W. Fitchett, R. P. Buck : ibid., 45, 1027 (1973).

12) J. F. Jaworski, G. H. Morrison : ibid., 46, 2080 (1974).

13) G. H. Morrison, B. N. Colby : ibid., 44, 1206 (1972).

14) O. H. Howard : ibid., 44, 1482 (1972).

15) A. W. Fitchett, R. P. Buck, P. Mushak : ibid., 46, 710 (1974).

\section{$\hat{2}$}

Determination of impurity elements in steel by spark source mass spectrometry using powdered salts. Morimasa SAITo and Emiko Sudo (National Research Institute for Metals, 2-3-12, Nakameguro, Meguro-ku, Tokyo)

Determination of impurity elements in steel by speak source mass spectrometry using powdered salts sample electrode was studied. The instrument used in this study was an AEI MS-7 mass spectrograph and the ion detector was Ilford Q2 photograph. Sample, $(0.5 \sim 1)$ gram, was dissolved in hydrochloric acid $(1: 1)$ or nitric acid $(1: 1)$ together with yttrium of 1 microgram as the internal standard and then the solution was evaporated to dryness without baking. The salt residues were dried at $70^{\circ} \mathrm{C}$ for 30 minutes under vacuum. They were mixed with an equal amount of graphite powder for 5 minutes in a mixer mill, and then pressed into electrodes.

When the relative sensitivity coefficient $(\mathrm{Fe}=1)$ was determined by using NBS 460 series standard samples, the results obtained by the proposed method for elements of Mo, Sn, Cu, Cr, Co, Ni, Mn, V, P, Si, and $\mathrm{B}$ were in good agreement with those obtained by the conventional method using solid sample electrodes (the solid method) and the precision of this method for 11 elements mentioned above was about $10 \%$ better than those of the solid method. However, both the accuracy and precision for elements of $\mathrm{Nb}$, Ti, S and W were not good. This method was applied to the determination of impurities in NBS stainless steel and others. The relative standard deviations were within $20 \%$.

(Received Mar. 12, 1975)

\section{Keywords}

Boron

Chromium

Cobalt

Copper

Iron and steel analysis

Manganese

Molybdenum

Phosphorus

Powdered salts electrode

Spark source mass spectrometry

Tin 